\title{
Sistem Informasi Pelayanan Warga RW 01 Kelurahan Rawa Buaya Berbasis Website
}

\author{
Rizki Akbar ${ }^{1}$, Esron Rikardo Nainggolan ${ }^{2}$, Siti Nur Khasanah ${ }^{3}$ \\ 1,2,3 Teknik Informatika, STMIK Nusa Mandiri Jakarta, Jl. Damai no. 8 Warung Jati Barat (Margasatwa) \\ Jakarta Selatan, D.K.I. Jakarta, Indonesia, 12540 \\ email: 1'rizkiakb2006@ nusamandiri.ac.id, ${ }^{2}$ esron.ekg@nusamandiri.ac.id, ${ }^{3}$ siti.skx@ nusamandiri.ac.id
}

\begin{abstract}
The process of managing data for residents in RW 01 RT 003 Kelurahan Rawa Buaya currently running, there are several identified problems, namely difficulties in finding data because it is still stored in the form of an agenda, making a cover letter that must take a long time because it is still manually recorded. The purpose of this thesis report is to design a citizen service information system using the waterfall method and for modeling the system using UML while the programming language uses PHP and for Database using MySQL. The results of this study indicate that the use of a citizen service information system can help the registration and data collection of residents in managing moving data and the process of making reports on monthly population and transparency in local RT finances as expected.
\end{abstract}

Keywords : Citizen Service, Citizen Data Collection, System Information, Population, Website

\section{Pendahuluan}

Perkembangan teknologi Informasi sekarang ini semakin cepat dan mudah diakses hal ini sejalan dengan hadirnya revolusi industri 4.0 (Prihandoyo, 2018) menyatakan bahwa teknologi informasi merupakan hal yang tidak dapat dipisahkan dari kehidupan saat ini, hal ini terlihat dari proses untuk mendapatkan informasi yang dapat diperoleh dengan cepat, tepat, serta akurat dikarenakan didukung oleh kemajuan teknologi yang semakin canggih.

Dengan kecanggihan teknologi Informasi saat ini dapat mempermudah perkerjaan dalam segala bidang. Perkembangan teknologi menjadikan masyarakat menginginkan adanya kemudahan dalam mendapatkan berbagai mancam informasi yang ada (Budianto \& Nainggolan, 2016). Pengguna teknologi dapat mencari informasi yang dibutuhkan serta dapat memperluas jaringan komunikasi menggunakan kecanggihan teknologi Informasi dan komunikasi. Salah satu teknologi yang banyak digunakan saat ini oleh kalangan masyarakat adalah komputer (Haswan, 2018). Majunya perkembangan teknologi di saat ini membuat penyebaran informasi tidak hanya melalui media offline melainkan Media online turut memberikan kontribusinya dalam menyampaikan informasi yang ada kepada para pencari informasi, seperti menggunakan media website (Krisnayani, Arthana, \& Darmawiguna, 2016).
Sistem informasi merupakan suatu sistem buatan manusia yang terdiri atas sekumpulan komponen/bagian atau elemen dalam organisasi guna menyajikan kebutuhan transaksi setiap harinya, mendukung operasi, bersifat manajerial dan kegiatan perencanaan dari suatu organisasi serta menyediakan informasi yang dibutuhkan kepada pihak pemakai (Puastuti \& ABB, 2017). Contohnya seperti pendataan penduduk di suatu daerah yang masih manualbisa diganti dengan sebuah sistem pendataan penduduk yang lebih modernsehingga proses rekap data penduduk bisa menjadi lebih baik dan akurat. Data adalah fakta-fakta dan gambar mentahan yang akan diproses atau diolah menjadi informasi (Fauzan \& Latifah, 2015).

Permasalahan yang sering terjadi pada RT/RWadalah kurang terorganisasinya pengarsipan data penduduk, masih tersimpan dalam buku induk RT/RW yang dicatat dengan tulisan tangan (Septiani, 2018). Perekapan data di warga RT.003/RW.01 Rawa buaya saat ini menggunakan buku agenda manual untuk menyimpan data penduduk dan data pembayaran iuran warga. Penanganan arsip suatu organisasi masih dapat dikatakan tidak efisien karena masih menerapkan sistem informasi konvensial dan memakan waktu untuk penemuan kembali apabila dibutuhkan (Latif \& Pratama, 2015). Permasalahan yang terjadi jika perekapan data masih menggunakan buku agenda manual, file yang ada di dalam buku agenda bisa hilang, 
kebakar atau pun terkena banjir, sehingga kita harus melakukan pendataan ulang, jika menggunakan media penyimpanan yang lebih modern masalah-masalah tersebut bisa dihindari. Contohnya tempat penyimpanan menggunakan database maka jika sewaktu waktu terjadi kehilangan berkas maka data tersebut tidak akan hilang karena sudah disimpan di media internet atau dengan kata lain database. selain itu, untuk proses pencarian data yang sewaktu waktu diinginkan oleh user maka waktu yang diperlukan lebih cepat daripada harus mengecek satu persatu buku penyimpanan data, karena pada sistem ini menggunakan fitur search engine di mana data penduduk yang telah disimpan di dalam database bisa diakses dengan lebih cepat sehingga lebih efektif dari pada harus mencari satu persatu di buku. Adanya inovasi baru melalui website diharapkan dapat mempermudah pengurus dalam hal ini RW dan RT dalam melayani masyarakat dalam urusan administrasi, kegiatan maupun dalam hal mendapatkan informasi seputar warga (Nainggolan \& Susafa'ati, 2018).

\section{Metode Penelitian}

Dalam penelitian ini beberapa metode penelitian yang digunakan. Metode yang digunakan dijelaskan pada subberikutnya.

\subsection{Metode Pengumpulan Data}

Dalam Penelitian ini penulis mengumpulkan data dengan cara sebagai berikut:

a. Observasi

Melakukan kunjugan dan pengamatan proses pendataan warga dan pembuatan surat-menyurat untuk warga RW.01 Khususnya RT.003 Kel.Rawa Buaya Jakarta.

b. Wawancara

Dalam metode wawancara ini, penulis mencoba mewawancarai ketua RT setempat yang bernama Bapak. Ade, untuk mendapatkan informasi berkaitan dengan kegiatan pendataan dan surat-menyurat.

c. Studi Kepustakaan

Dengan mempelajari permasalahan yang berkaitan dengan proses penyimpanan data penduduk yang masih manual. Proses pembelajaran materi dilakukan dengan kajian berbagai sumber pustaka baik berupa buku, jurnal ilmiah, maupun media elektronik.

\subsection{Metode Pemgembangan perangkat Lunak}

Berikut adalah metode penelitian yang penulis lakukan pada RT.003/RW.01 Kelurahan Rawa buaya Jakarta dalam penelitian ini adalah :

Menurut (Ramadhan \& Utomo, 2014) Metode Waterfall merupakan suatu proses pengembangan perangkat lunak yang sequensial/ berurutan, di mana proses pengerjaannya terus mengalir dari atas ke bawah (seperti konsep air terjun) dengan tahapannya diataranya analisis kebutuhan, perancangan dan pemodelan, penerapan, pengujian, dan pemeliharaan.

Untuk mendapatkan data dan informasi yang diperlukan, penulis menggunakan metode pengembangan sistem waterfall, yang tahapannya sebagai berikut:

\section{a. Analisa Kebutuhan Sistem}

Dibutuhksn sistem informasi pelayanan warga secara online berbasis website dimana jika ini membuat surat-menyurat tidak harus bertatap muka secara langsung, warga bisa membuat surat-menyurat memalui halaman website tersebut.

\section{b. Desain}

Penulis mendesai sebuah website sistem informasi agar dapat digunakan untuk mempermudah pelayanan atau pun penyebaran informasi kepada seluruh warga, semua ini bermaksdu untuk memudahkan sistem informasi secara terkomputerisasi dalam membuat web, penulis merancang sistem menggunakan UML (Unified modeling language), merancang dengan menggunakan ERD (Entity Relationship Diagram) dan LRS (Logical Record Structure).

\section{c. Implementation}

Mentransformasikan desain ke dalam bentuk program dan pemilihan bahasa, Serta menerjemahkan data yang telah dirancang ke dalam bahasa pemrograman yang telah ditentukan. Dalam program ini bahasa yang di gunakan PHP (Hypertext Preprocessor), HTML (Hyper Text Markup Language). CSS (Cascading Style Sheet). JavaScript, dan Database MYSQL.

\section{d. Verification}

Pengujian sistem bertujuan menemukan kesalahan-kesalahn yang terjadi pada sistem dan melakukan revisi sistem. Tahap ini penting untuk memastikan bahwa sistem bebas dari kesalahan. Pengujian sistem yang di buat menggunakan Blackbox testing. 


\section{e. Maintanance}

Tahapan pendukung atau pemeliharaan dapat mengulangi proses pengembangan mulai dari analisis spesifikasi untuk perubahan perangkat lunak yang sudah ada tapi tidak membuat perangkat lunak baru, Tahap pendukung Hardware untuk penelitian ini adalah satu unit laptop dengan sistem operasi Windows 7 Ultimate, sedangkan Software yang digunakan untuk pembuatan sistem ini menggunakan Sublime dan Database-nya menggunakan XAMPP,dan untuk publikasi-nya menggunakan Domain dan Hosting.

\section{Hasil Dan Pembahasan}

\subsection{Hasil}

Sebagai gambaran umum dari hasil analisa perancangan system pelayanan warga maka studi kasus dilakukan di RT 003 RW 01 Kel.Rawa buaya. Hasil Analisa kebutuhan (system requirement) dari sistem informasi pelayanan warga yang dianalisa sebagai berikut:

Halaman Administrator / Ketua RT:

1. Admin dapat login halaman pengurus RT

2. Admin dapat mengelola pendataan warga baru

3. Admin dapat mengelola surat mutasi

4. Admin dapat membuat surat pengantar

5. Admin dapat mengelola informasiinformasi bulanan

6. Admin dapat mengelolah laporan keuangan

7. Admin dapat logout

Halaman User / Warga:

1. User dapat login halaman warga

2. User dapat melihat daftar warga

3. User dapat melihat informasi harian atau bulanan

4. User dapat melakukan pengajuan surat pengantar

5. User dapat melihat laporan keuangan RT

6. User dapat logout

Dapat digambarkan pada diagram berikut:

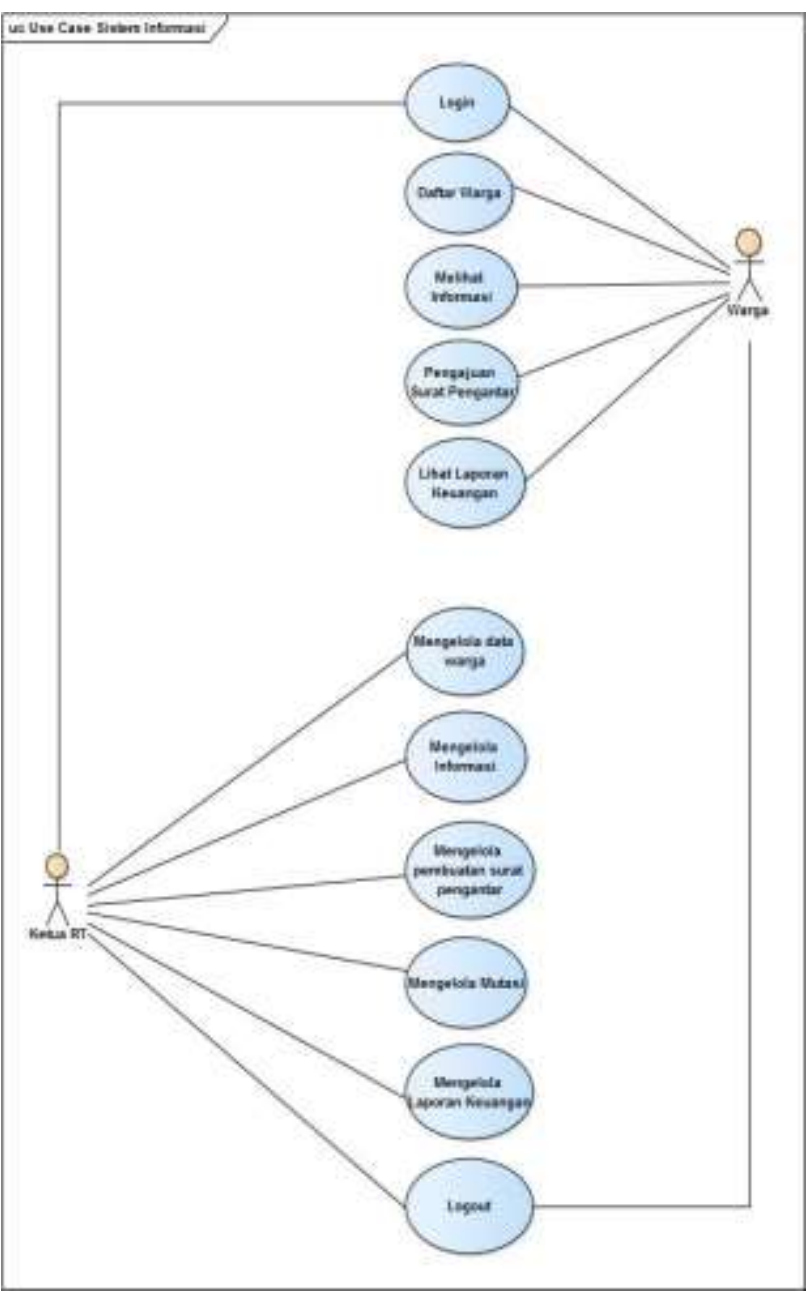

Gambar 1. Use Case Diagram Sistem Pelayanan Warga

Dari pengambaran ssitem menggunakan UMl tersebut dibuatkanlah kedalam implementasi yaitu menggunakan Bahasa pemograman PHP, HTM dan Javascript. Hasil dan pembahasan dari penelitian yang telah dilakukan yaitu sudah terpenuhinya segala sesuatu kebutuhan system yang diinginkan oleh pengurus setempat (Admin/RT/RW) dan warga (user). Adapun produk akhir sebagai berikut:

1. Tampilan laman Utama, untuk memilih menu login sesuai dengan hak aksesnya. 


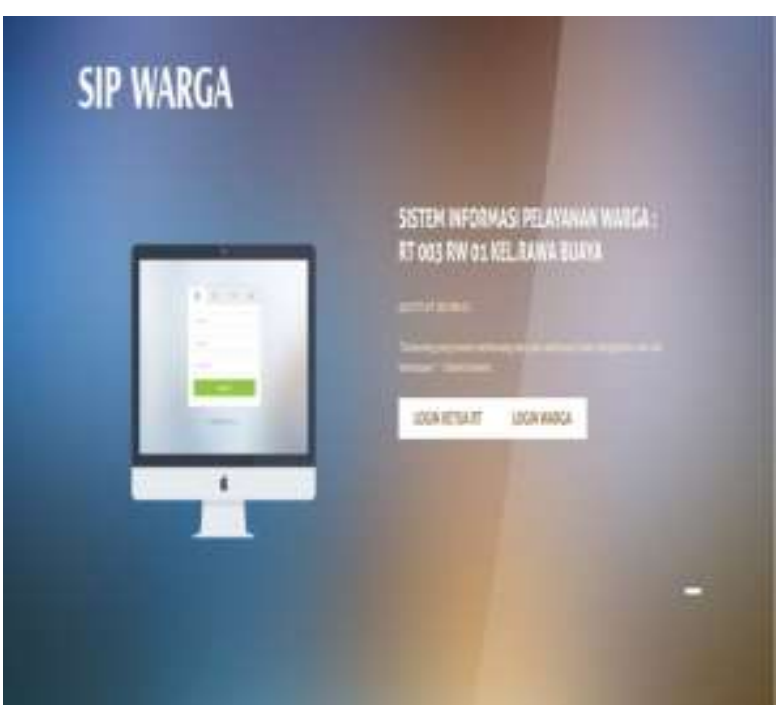

Gambar 2. Tampilan Halaman Utama

2. Laman Form Login, laman ini digunakan untuk masuk/ melakukan verifikasi kedalam sistem. Dan membatasi hak akses Seorang pengguna baik Pengurus atau Warga, apabila username atau password tidak terdaftar didatabase maka tidak akan bisa melakukan akses kedalam system pelayanan warga.

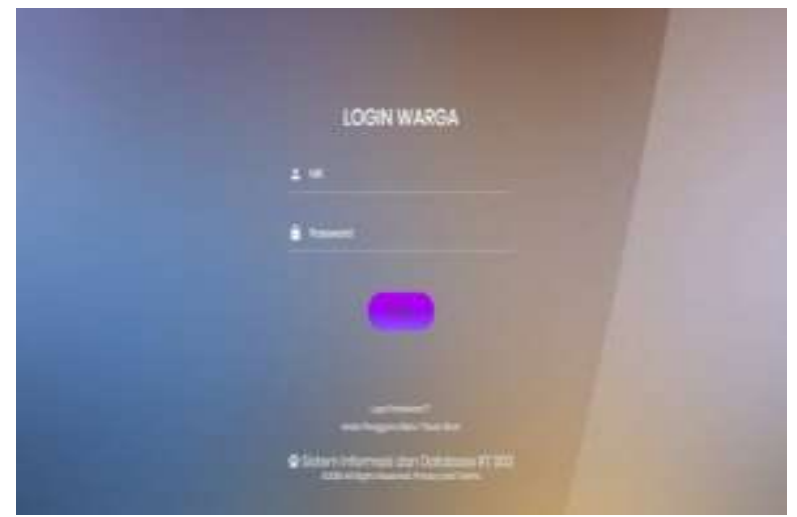

Gambar 3. Halaman Login

3. Tampilan Beranda

Tampilan ini berisi menu utama sesuai dengan fituryang ada di system pelayanan RW.
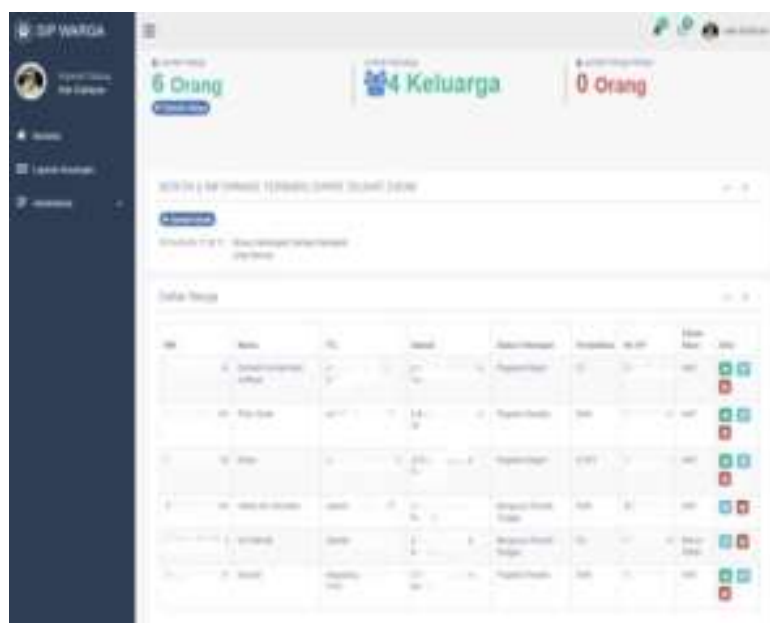

Gambar 4. Halaman Utama

4. Form Tambah Warga Baru

Form yang digunakan untuk melakukan input pendataan warga baru.

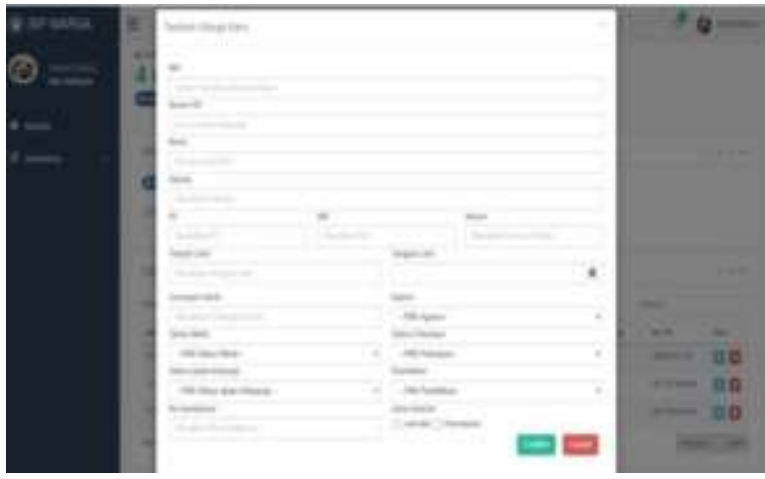

Gambar 5. Form Input Warga Baru

5. Form Pengajuan Surat Pengantar

Form yang digunakan untuk pengajuan surat pengantar sesuai kebutuhan warga

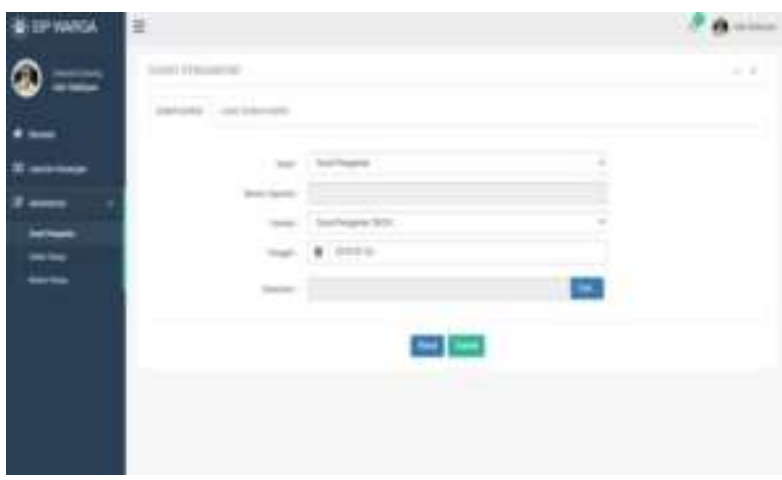

Gambar 6. Halaman Pembuatan Surat Pengantar

6. Bentuk Surat Pengantar

Berikut bentuk surat pengantar yang dihasilakn dari system pelayanan warga: 


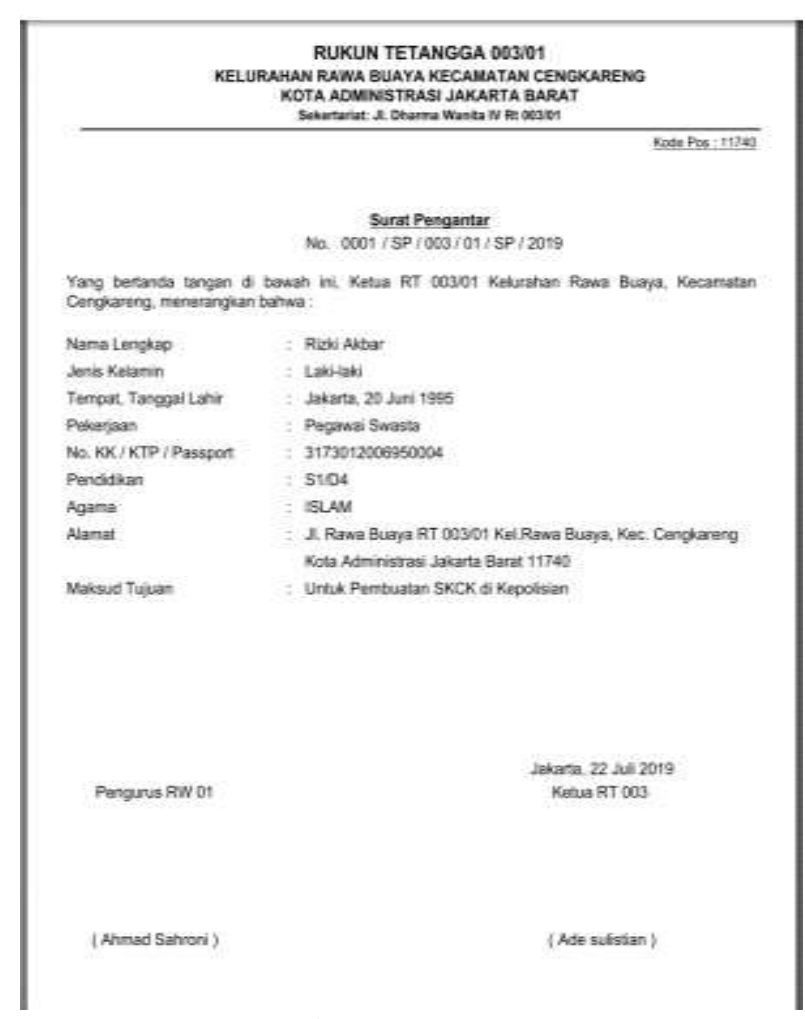

Gambar 6. Surat pengantar

Dari setiap unit progam yang ada dilakukan pengujian fungsionalitas system pelayanan warga RW 01 dengan menggunakan metode backbox testing. Pengujian dilakukan dengan cara memberikan input pada komponen menu/fungsi program yang diuji, selanjutnya diperiksa hasil dari output yang keluar dari proses. Hasil pengujian unit program yaitu berupa status validasi unit yang dapat dikatakan valid/sesuai apabila output yang dihasilkan benar/ sesuai dan tidak valid/ tidak benar apabila output yang dihasilkan tidak sesuai atau terdapat error atau salah kodingan. Hasil pengujian fungsional yang dilakukan pada menu/ fungsi pada system pelayanan warga disimpulkan $100 \%$ valid artinya sesuai dengan yang diinginkan dan system pelayanan warga ini layak untuk diterapkan.

\subsection{Pembahasan}

Berdasarkan hasil analisa mengenai program sistem informasi pelayanan warga RW 01 Kelurahan Rawa buaya sudah melalui beberapa tahapan dan ujicoba. Tahapan pertama yaituanalisa dilanjutkan ke desain yang dilakukan oleh penulis dan di uji coba kepada pengurus RT setempat dengan mudah, membuktikan bahwa desain sistem informasi pelayanan warga ini dinyatakan sangat baik dan mudah untuk di gunakan. Tahapan selanjutnya yaitu pengujian produk oleh warga (user) ditempat penelitian RT 003 / RW 01 Kelurahan Rawa Buaya .Hasil keseluruhan pengujian produk oleh warga (user) terbilang cukup puas karna dengan program sistem informasi ini warga (user) dengan mudah melakukan pengajuan surat-menyurat, dengan kesimpulan bahwa sistem pelayanan warga yang dibangun dapat digunakan tanpa revisi. Kesimpulan secara umum yaitu system pelayanan RW berjalan sangat baik. Melalui setiap proses tahapan pengembangan sistem yang sudah dilakukan dan juga melalui proses validasi desain sistem oleh penulis dan pengujian produk system pelayanan Warga oleh Pengurus (diataranya RT dan RW) ataupun warga (sebagai user) maka dapat disimpulkan bahwa sistem informasi pelayanan warga RW. 01 yang dibuat sudah bisa menyelesaikan sedikitnya masalah-masalah mengenai pendataan warga RW.01, surat-menyurat dan berbagai informasi lainnya

\section{Kesimpulan dan Saran \\ 4.1 Kesimpulan}

Kesimpulan dari penelitian ini yaitu terbentuknya system informasi warga yang dapat mempermudah dalam menjalankan Sistem Pendataan warga baru,pengajuan surat-menyurat dan informasi bulanan. Dengan dibangunnya Sistem informasi pelayanan warga ini, maka dapat ditarik beberapa kesimpulan, yaitu:

1. Dari hasil penelitian yang dilakukan di RT 003 RW 01 Kelurahan Rawa buaya, dapat disimpulkan bahwa dalam Sistem Informasi Pelayanan Warga Berbasis Web dapat mengefisiensikan waktu sehingga proses pendataan warga baru dan pengajuan suratmenyurat berlangsung cepat dikarenakan tidak menggunakan tulisan tangan lagi dalam proses surat menyurat.

2. Dengan menggunakan Sistem Infromasi Pelayanan Warga Berbasiskan Web yang dirancang menggunakan PHP dan MySQL, Para warga baru tidak mengalami kesulitan lagi dalam memperoleh informasi warga, pengajuan surat-menyurat maupun informasi lainnya.

3. Dengan adanya Sistem Pelayanan Warga Berbasiskan Web yang sudah di buat, bagian Pengurus ataupun Ketua RT tidak kerepotan untuk membuat laporan dari hasil seluruh pendataan warga maupun informasi bulanan 


\subsection{Saran}

Adapun saran yang penulis uraikan diharapkan berguna bagi penelitian ini ataupun berguna bagi lingkungan RT 003 RW 01 Kelurahan Rawa Buaya sekarang, dan pengembangan untuk Sistem Informasi Pelayanan Warga Berbasikan Web ini kedepannya.

1. Dengan adanya Sistem Informasi Pelayanan Warga Rw 01 Kelurahan Rawa Buaya Berbasis Website ini, maka disarankan adanya penelitian untuk pengembangan kedepannya untuk memudahkan warga baru untuk memperoleh informasi yang diharapkan.

2. Sebaiknya Sistem Informasi Pelayanan Warga RW 01 Kelurahan Rawa Buaya Berbasis Website ini dapat dikembangkan menjadi Sistem Informasi Pelayanan Warga Berbasis mobile yang dilengkapi dengan chat interaktif dan user interface yang mudah di pahami bagi para warga, dan memberikan tambahan notifikasi melalui $e$ mail atau pun sms gateway.

\section{Daftar Pustaka}

Budianto, A., \& Nainggolan, E. R. (2016). Perancangan Aplikasi Islamic Boarding School Finder. In Sniptek 2016 (pp. 144-150).

Fauzan, R., \& Latifah, R. (2015). Audit Tata Kelola Teknologi Informasi Untuk Mengontrol Manajemen Kualitas Menggunakan Cobit 4.1 ( Studi Kasus: PT Nikkatsu Electric Works ). Jurnal Teknik Informatika Dan Sistem Informasi, 1(3), 235-244.

Haswan, F. (2018). Perancangan Sistem Informasi Pendataan Penduduk Kelurahan Sungai Jering
Berbasis Web Dengan Object Oriented Programming. Jurnal Teknologi Dan Open Source, 1(2), 92-100.

Krisnayani, P., Arthana, I. K. R., \& Darmawiguna, I. G. M. (2016). Analisa Usability Pada Website UNDIKSHA Dengan Menggunakan Metode Heuristic Evaluation. Kumpulan Artikel Mahasiswa Pendidikan Teknik Informarika (KARMAPATI, 5(2), 1-10.

Latif, F., \& Pratama, A. W. (2015). Perancangan Sistem Informasi Manajemen Arsip Elektronik (E- Arsip) Bebrasis Microsoft Acces Pada PT. HI-TEST. Jurnal Akutansi, Ekonomi Dan Manajemen Bisnis, 3(1), 21-31.

Nainggolan, E. R., \& Susafa'ati. (2018). Rancang bangun sistem informasi pelayanan rukun warga pada rusunawa pesakih jakarta barat. In Seminar nasional Ilmu Terapan (SNITER 2018)- Universitas Widya kartika (pp. 1-6). Surabaya, Indonesia.

Prihandoyo, M. T. (2018). Unified Modeling Language ( UML ) Model Untuk Pengembangan Sistem Informasi Akademik Berbasis Web. Jurnal Informatika: Jurnal Pengembangan IT (JPIT), 03(01), 126-129.

Puastuti, D., \& ABB, K. S. (2017). Perancangan Sistem Informasi Pendataan Warga Sekolah Berbasis Web Pada SDN 2 Pagelaran. JPGMI, 3(1), 26-42.

Ramadhan, T., \& Utomo, V. (2014). Rancang Bangun Aplikasi Mobile Untuk Notifikasi Jadwal. Jurnal Teknologi Informasi Dan Komunikasi,5(1), 47-55. https://doi.org/10.1234/JTIK.V5I2.93

Septiani, W. D. (2018). Sistem Informasi Pengelolaan Data Penduduk ( Studi Kasus : RT / RW Kelurahan Pondok Kacang Timur ). Jurnal Ilmu Pengetahuan Dan Teknologi Komputer, 4(1), 23-28. 